\title{
Making the Water-Soil-Waste Nexus Work: Framing the Boundaries of Resource Flows
}

\author{
Tamara Avellán ${ }^{1, *},+$ (i) , Mario Roidt ${ }^{1,+}{ }^{\dagger}$, Adam Emmer ${ }^{2}$ (D) , Janis von Koerber ${ }^{3}$, Petra Schneider ${ }^{3}$ \\ and Wolf Raber ${ }^{4}$ \\ 1 Water Resource Management Unit, Institute for Integrated Management of Material Fluxes and of \\ Resources (UNU-FLORES), United Nations University, 01067 Dresden, Germany; roidt@posteo.de \\ 2 Department of Human Dimensions of Global Change, Global Change Research Institute (CzechGlobe), \\ Czech Academy of Sciences, 60300 Brno, Czech Republic; emmer.a@czechglobe.cz \\ 3 Department Water, Environment, Civil Engineering and Safety, \\ University of Applied Sciences Magdeburg-Stendal, Breitscheidstr. 2, D-39011 Magdeburg, Germany; \\ janiskoerber@msn.com (J.v.K.); petra.schneider@hs-magdeburg.de (P.S.) \\ 4 inter $3 \mathrm{GmbH}$ Institute for Resource Management, 10585 Berlin, Germany; raber@inter3.de \\ * Correspondence: avellan@unu.edu; Tel.: +49-351-8921-9380 \\ + These authors contributed equally to this work and are considered to be co-first authors.
}

Received: 29 June 2017; Accepted: 11 October 2017; Published: 19 October 2017

\begin{abstract}
The Sustainable Development Goals have placed integrated resources management, such as integrated water resource management, at the heart of their targets. The upcoming "International Decade for Action—Water for Sustainable Development", 2018-2028 has highlighted the importance of promoting efficient water usage at all levels, taking into account the water, food, energy, and environmental nexus. While integrated resource management approaches have been defined and applied for decades, nexus approaches are more recent. For these latter approaches to be implemented on the ground, their system boundaries need to be clarified. While the Water-Energy-Food Nexus focuses on sectors, the Water-Soil-Waste Nexus addresses linkages between environmental resources-namely water, soil and waste-to tackle sustainable management. In this paper, we analyzed integrated management systems and how their system boundaries are defined. From this we determined that in order for system boundaries to be applicable, they should be clear, wide and flexible. Based on this, we propose the boundary of the Water-Soil-Waste Nexus system. We use two case studies to exemplify the usefulness of these system boundaries.
\end{abstract}

Keywords: integrated water resources management; integrated natural resources management; integrated solid waste management; Water-Energy-Food Nexus; boundary

\section{Introduction}

In September 2015, the United Nations Member States adopted the Sustainable Development Goals (SDGs) to promote a global transformation towards more sustainability. The SDGs are more comprehensive than their predecessors, the Millennium Development Goals, which were often criticized for not adequately considering the environmental dimension of sustainability. Water and the integrated management of natural resources are important and interlinking subjects in the SDGs. Hence the United Nations General Assembly, as of 25th November 2016, encouraged member states and all relevant partners to contribute to the International Decade for Action, "Water for Sustainable Development", 2018-2028. The upcoming "Water Decade" builds on the momentum gained during the International Decade for Action, "Water for Life", 2005-2015, in order to support the implementation of the SDGs. 
The discussion that resource management needs greater integration reaches beyond the SDGs. It is ongoing in science and intergovernmental meetings since the middle of the 20th century [1]. Integrated water resources management (IWRM) has a long history—of over half a century [2,3]. Consequently, and with the momentum of sustainable development in the 1990s, different integrated environmental management approaches appeared. Examples besides IWRM [3-6], are integrated natural resources management (INRM) $[1,7,8]$ and integrated solid waste management (ISWM) $[9,10]$. In general, these approaches aim at optimizing the use of one compartment while considering its effect on related fields. Common to these approaches is a holistic view (e.g., INRM [11], ISWM [10], IWRM [12]) and a systems approach (INRM, IWRM [1], ISWM [10]).

\subsection{Definition of Concepts: Systems, Systems Analysis and Boundaries}

Holism requires systems analysis. Smithson et al. [13] mention that systems analysis is a method to investigate complex systems and define it as "... the study of systems, for example hydrological systems, atmospheric systems and ecosystems in physical geography." (p. 752). A system is defined as "a set of interconnected parts which function together as a complex whole" ([13], p. 9). It is characterized by processes (e.g., fluxes), stores (e.g., a soil profile) and subsystems (e.g., groundwater in the hydrologic cycle) [ibid.]. The processes are often the key component to understand the system. In this article, we refer to processes as strictly (bio-)physical processes in the natural environment or in urban systems (e.g., water or waste fluxes).

Systems within the physical environment (see e.g., [13,14]) are located within a boundary [15]. Within this context, we understand the system boundary as the borderline (limit) that marks the geographic area (extent) of a system. It is the area in which physical processes are sought to be analyzed in systems analysis.

Environmental systems are most often so-called open systems, where matter and energy may transfer across system boundaries (both in and out) [15]. Examples are agricultural ecosystems or aquifer systems. Water enters and exits the system across their geographic boundary. The chosen boundaries define the system under analysis. In hydrology the chosen catchment size depends on whether the water system of a large river or of only one of its tributaries is analyzed. The inputs and outputs to the system can vary significantly depending on the chosen system boundary. Environmental systems are interlinked and often not easy to separate; yet when applying systems analysis, the system under investigation needs to be clearly described by defining its boundaries, for instance for the set-up of numerical models. Defining the boundaries is important and often challenging. Meadows and Wright [16] put clear words to it in saying that " ... if we're to understand anything, we have to simplify, which means we have to make boundaries" (p. 97). They go on to explain that "... where to draw a boundary around a system depends on the purpose of the discussion"; and "... the lesson of boundaries is hard even for systems thinkers to get. There is no single, legitimate boundary to draw around a system. We have to invent boundaries for clarity and sanity [ ... ]" [ibid.]. It is exactly the purpose of this paper to describe the boundary of the water-soil-waste system in order to make the Water-Soil-Waste Nexus Approach (WSW Nexus) operational, yet keeping in mind that the scale of the WSW Nexus may not be identical to the boundaries of the WSW System (see on that issue e.g., [17]).

\subsection{The Rationale for Framing the Boundaries of Resource Flows}

As the definition of boundaries is crucial to systems analysis, a question that all approaches have to address is: what are the boundaries of a system within which the interlinkages can be most effectively grasped and analyzed? The integrated approaches under analysis in this article (IWRM, INRM, ISWM) have addressed interlinking principles within holistic management in the past decade (examples are [5-7,18], see also more detail in Sections 2 and 3).

In recent years the nexus debate entered the discussion of integrated management with the Water-Energy-Food Nexus (WEF Nexus) [19]. The novelty in this approach lies in revealing tradeoffs and synergies to be considered in decision making amongst sectors aiming at food, energy and water 
security [ibid.]. There are some examples of analyses and methods to assess the WEF Nexus (see [20,21]); yet Cairns and Krzywoszynska report that there is a " ... lack of clarity or consensus around the degree to which there is a recognizable 'nexus methodology'." ([22], p. 166). The WEF Nexus also does not seem to be clear regarding a boundary that marks something like a water-energy-food system (see also Section 2.5).

By focusing the debate on the interlinkages of resources and resource flows, the WSW Nexus intends to show the benefits of an integrated assessment and management of the resources soil, water and waste [23]. As an even younger concept than the WEF Nexus, the WSW Nexus is lacking a clear methodology for its implementation or operationalization on the ground as well as a common definition within which boundaries resources interlinkages are most effectively analyzed. With this present study we want to understand which elements are needed to make the WSW Nexus applicable to real world examples. A first step in systems analysis is the definition of the boundary of the system, with this in mind, we aim at assessing which boundary may be the most effective one when analyzing water, soil and waste flows of the water-soil-waste resources system.

To define the boundaries of the WSW Nexus as a new system we compare and contrast the question of boundaries of integrated management approaches that focus on any of the three resources: water, soil or waste. We attempt to describe the water-soil-waste resources system and its boundaries to derive the level at which the physical processes between water, soil and waste can be analyzed to create knowledge and eventually inform decision making in environmental governance.

The objectives of this paper are to (i) describe the systems of the integrated management approaches and the WEF and WSW Nexus, (ii) examine the boundaries of systems analysis in these approaches and draw lessons learned, (iii) based on this, propose the system boundary for the WSW Nexus and (iv) show-with two case studies-how this boundary is useful in the application of the WSW Nexus.

\section{An Overview of Integrated Approaches Related to the WSW Nexus}

Below is a brief description of the three integrated management approaches (ISWM, INRM, IWRM) and the two nexus approaches (WEF, WSW).

\subsection{Integrated Solid Waste Management}

ISWM grew out of the waste management constituency as an approach to handle the increasing amounts of solid waste generated in the developed world in the past decades. The idea is that the many options of waste management in collecting, transporting, treating and disposing of waste must not only be considered in simple comparisons, but scrutinized following an approach that can improve economic and ecological efficiency through systemic and scientific approaches [24].

The definition of integrated waste management is given in the prominent book, Integrated Solid Waste Management [9].

"Integrated Waste Management systems combine waste streams, waste collection, treatment and disposal methods, with the objective of achieving environmental benefits, economic optimisation and societal acceptability. This will lead to a practical waste management system for a specific region." ([9], p. 15)

In ISWM, it is not necessarily the case that one resource (waste) is integrated with other environmental resources. It is rather the integration of different waste materials, sources of waste, collection practices, as well as a combination of the varying treatment methods such as incineration, anaerobic digestion, landfilling or recycling [9]. The European Commission went beyond the goals of ISWM. In communication COM/2014/0398, the EU discusses the concept of the circular economy towards a zero-waste program for Europe. The overall scope of a circular economy approach in ISWM is to reduce residual waste streams as far as possible in order to close material cycles. This is an objective that is also aimed to be achieved in developing countries [25]. 


\subsection{Integrated Natural Resources Management}

INRM grew out of the agricultural constituency as a research and development paradigm. The approach of INRM is a systems approach that aims to impact the quantity and quality of more than one resource [1].

The definition we refer to in this paper of INRM stems from the Consortium of International Agricultural Research Centers (CGIAR), organized as a global agricultural research partnership with a similar structure to the Global Water Partnership (GWP). At its second workshop on INRM research in the CGIAR in 2000, the INRM approach was defined as:

“... a conscious process of incorporating multiple aspects of natural resource use into a system of sustainable management to meet explicit production goals of farmers and other uses (e.g., profitability, risk reduction) as well as goals of the wider community (sustainability)". ([7], p. 5)

INRM is thus an approach that focuses on improving the life of farmers at the farming or household level through applied integrated research, participation, continued adaptation and learning.

\subsection{Integrated Water Resources Management}

Hydrologists and water engineers-familiar with systems analysis-used the increasing environmental awareness and global sustainable policy momentum in the 1990s to put forward the approach of IWRM [26] as a systems approach to the study of water resources [1] and an interdisciplinary and holistic way of managing them.

The approach was coined with milestones such as the Dublin Principles and the Agenda 21 in 1992, the foundation of the GWP and the World Water Council in 1996 and the decision to prepare integrated water resources management and water efficiency plans at the Earth Summit in Johannesburg 2005.

The definition of IWRM that is most widely accepted was given by GWP in 2000 stating that IWRM is:

“... a process which promotes the coordinated development and management of water, land and related resources, in order to maximize the resultant economic and social welfare in an equitable manner without compromising the sustainability of vital ecosystems." ([18], p. 22)

Today, IWRM is the leading and most widely accepted paradigm of water management. Even though controversially discussed and criticized the aim of implementing IWRM around the globe is ongoing, with varying levels of success. The dedication of SDG 6.5 to IWRM shows its high level of importance on the agenda in today's approaches to manage water resources [27].

\subsection{The Water-Energy-Food Nexus}

The increasing scarcity of water, food and energy and an increasing demand by a growing populations and changing lifestyles were called the "perfect storm" to arise in 2030 by Beddington [28], who strikingly described the inextricable linkages between the nexus compartments.

Some years later-with a report on the Water-Food-Energy-Climate Nexus by the World Economic Forum, the nexus conference background paper "Understanding the Nexus" by Hoff [19] and its proceeded conference on the WEF Nexus in Bonn-the WEF Nexus gained momentum in international organizations until today [29].

A generally agreed-upon definition of a nexus approach has not yet emerged. However, at the dawn of the nexus approach and in preparation for the Bonn 2011 nexus conference, the background paper prepared by Hoff [19] has greatly influenced the shaping of the approach. In his view, the WEF Nexus lies within the context of achieving water-, energy-, and food security in an emerging green economy. Within that context, the WEF Nexus aims to support such a transition through achieving greater policy coherence and higher resource use efficiency [ibid.]. Through reducing 
trade-offs and building synergies, the intentions of the WEF Nexus are to increase the security of water, energy and food, which would result in secure access for all the worlds people [ibid.]. This is based on three principals: (1) "investing to sustain ecosystem services" as they lay the basis of our needs as natural capital, which can draw on investment when incorporated into national accounting; (2) "creating more with less", as the green economy depends on amplified efficiency to combat resources scarcity; (3) "accelerating access, integrating the poorest" aims to reduce poverty, while accelerating development and sustainability ([19], pp. 14-15).

\subsection{The Water-Soil-Waste Nexus Approach}

The WSW Nexus is in close relationship to the WEF Nexus [30]. While the WEF Nexus focuses on sectors, the WSW Nexus asks how resources should be managed to tackle sustainable management [30]. In particular, the addition of waste as a resource dimension that often gets omitted in the sector based approaches shall arguably result in more effective and efficient solutions to problems. By moving away from sectors to resources, the possibility for a stepwise approach of the analysis of the varieties and options of resource interlinkages is given. First, natural science processes such as material fluxes and respective scenario building can be assessed. Then corresponding socioeconomic benefits can be determined for the respective scenario options. Ultimately, context-specific solutions and potential overarching policy recommendations can be developed and chosen.

The WSW Nexus Approach is described as follows:

“The Nexus Approach to environmental resources' management examines the inter-relatedness and interdependencies of environmental resources and their transitions and fluxes across spatial scales and between compartments. Instead of just looking at individual components, the functioning, productivity, and management of a complex system is taken into consideration". [30]

The need and usefulness of the WSW Nexus is described by Hülsmann and Ardakanian [31] while Kurian and Ardakanian [32] assess the governance needs for the Nexus.

\section{The System Boundaries of Integrated Environmental Management Approaches}

In the following, we assess the boundaries of the previously described systems. We further describe their strengths and weaknesses in the context of the approach to draw lessons for the WSW Nexus.

\subsection{Integrated Solid Waste Management}

ISWM analysis takes place within municipal or intermunicipal boundaries that mark the waste system. The waste system is spatially comprised of the sources of waste, collection and transport as well as treatment including reuse, recycling or disposal [9]. It is apparent that this system is designed and operated by humans and is not spatially bound by environmental but social boundaries. ISWM aims to integrate the above mentioned waste related processes which mainly occur within the administrative boundaries of the municipality, also including the city or town level [33]. It is a strength of the waste system that in terms of waste flows within the municipality, the boundaries are clearly defined.

Several case studies and examples reflect these boundaries, such as the solid waste authority of the county of Palm Beach in the USA, the municipality of Kalundborg in Denmark [34], the city of Thessaloniki in Greece [35] or several other cities in Asia [36]. ISWM is also conducted in settings similar to municipalities such as the industrial park level in Tianjin city [37]. However, as the range of management options increases with integrated methods the boundary may also expand. McDougall et al. [9] describe that IWSM benefits from the economy of scale when organized on a larger level than a single municipality. They argue for an area upwards of 500,000 households. This requires combining 
waste streams of different municipalities which is already common practice since many years in several places around the world [ibid.].

Often the waste system does not operate strictly within a single municipality anymore with different processes (recycling, landfills, reuse) located outside a municipality's boundary [38]. In addition, the control of the waste management system is difficult, as waste management is often compartmentalized with several independent private operators that are in charge of collection or treatment steps [10]. Taking this into consideration expands the boundary of ISWM to an intermunicipal level wherever appropriate. For analysis of waste streams, it is a weakness that the boundary definition is prone to become ambiguous when it exceeds the municipal boundaries.

Waste systems can be analyzed by using Life Cycle Inventory Assessment [9] or Material Flow Analysis [39] approaches. Central to these methods is the definition of the boundary of the system. It is defined around the waste system, within municipal or intermunicipal boundaries.

\subsection{Integrated Natural Resources Management}

INRM is promoted mainly at a local level based on agroecosystems. However, a strong emphasis is also across different ecosystems and social boundaries. INRM focuses on the interactions of agricultural activities with the surrounding environment. On the one hand agricultural activities are to some extent derived and influenced by the conditions of ecosystems but are, on the other hand, heavily dominated by social arrangements rather than natural boundaries. Hence INRM aims to consider both boundaries.

The focus of INRM activity is often local. With its background in farming systems research, INRM seeks to build the capacity of farmers and other natural resources managers [40], while placing the farmer at the household or field level at the center of activities [41,42]. This is as strength in the approach, that when systems analysis is being conducted the farm level provides a tangible and practical boundary definition.

When looking at INRMs key principles, it can be seen that the approach reaches beyond the boundary of the farm level. INRM aims for "multiple scales" - spatially and temporally. Well aware of the complexity, Sayer and Campbell [43] recognized a biophysical component reaching from the single farming plot to the global level. In further descriptions of the approach the focus remains on the multitude of scales with the ecosystems as boundary of influence [39]. Hence ecosystems, or agroecosystems of varying sizes from plot level to ecozone or social units from the village to national level that cross scales and boundaries are discussed [42].

The boundary around the ecosystem or agroecosystem seems to remain constant. Yet the spatial dimension of scale is unclear (multitude of scales) and the boundary of the ecosystem seems unpractical when exceeding the farm level.

Examples of the INRM paradigm can be seen from case studies where the focus of analyzing the system was often local. Hagmann et al. [11] show how research spanned from the plot level up to the policy sphere. Different agricultural techniques were implemented at the farm level, such as soil fertility and water conservation. Afterwards, efforts were made to scale up to community, catchment or district level. Douthwaite et al. [40] introduce agricultural research projects on subcounty (in Uganda), village (in Nigeria) and pilot site scales (in Zimbabwe).

\subsection{Integrated Water Resources Management}

In IWRM, the boundaries for analyzing water resources is usually the river basin or catchment, derived from the water system i.e., the hydrological cycle. As water moves defined by natural boundaries, water quantity and quality can best be studied within the boundaries of the basin or catchment. As the approach of IWRM was derived from hydrologists and water engineers [26], the natural boundary of the basin is the preferred at which to assess water flows in contrast to socially constructed boundaries such as administrative borders. It is considered a strength of the approach that analysis of the water system is done bound by the basin as it is hydrologically speaking the most useful idea. 
That the basin is the logic unit for IWRM was consolidated in the Dublin Principle Nr.1, the Agenda 21 (Chapter 18.9) and in the defining work of GWP [18]. It further received positive attention in subsequent meetings such as the World Water Forums, the International Freshwater Conference in Bonn (2001) or the Johannesburg Earth Summit 2002 [44]. Since then, the basin as management unit in IWRM is widely accepted [12,44-47].

Major objectives of IWRM concerning the basin are the development of river basin plans and the establishment of river basin organizations. However, the World Water Development Report 2012 states that the implementation of these objectives to prepare and implement IWRM plans "remains unsatisfactory and well behind target" ([48], p. 139).

Hence, in recent years these objectives have received critique and it is questioned whether the basin is the appropriate unit to manage water resources. Many also warn to impose a common framework without bearing in mind the local or national specifications and are skeptical towards the capability of river basin organizations or countries to implement IWRM in an effective way [49].

Firstly, the critique concerns the problem of fit. Intangible values of economics and societies that reach beyond the edges of a river basin complicate the process of IWRM [50] and create a complicated overlapping of authorities in decision making [45]. The creation of river basin organizations as a solution may increase not only political resistance and radically different socioecological situations, but also raises issues of democratic representation and legitimacy (ibid.). Graefe [44] describes the shift to IWRM as a "depoliticizing of water management" with "expert environmental administrators" as decision makers rather than governments (p. 26).

Secondly the justification for the basin as a boundary of water is being challenged as variables can surpass the river basin boundary. Water physically flows beyond the river basin through interbasin transfer projects ( $14 \%$ of global water withdrawals). This is likely to quadruple institutional management complexity [51]. In addition, the concept of virtual water demonstrates how water is indirectly diverted between basins around the globe [50].

On the one hand, some cautiously question if the basin is the only appropriate unit in its broad sense for IWRM and show examples where nonintegrated management was successful to argue that alternatives to IWRM may not be ignored [52]. On the other hand, IWRM is heavily criticized for its "basin fetishism" and it is warned from privileging only one scale to the increasingly complex tasks of water management ([44], p. 26). What is hydrologically useful is altered due to human activities, revealing the weaknesses of systems analysis by using the basin as the boundary of water flows.

Despite the scholarly debate, assessments in the context of IWRM such as the modelling of surface water and groundwater quantity and quality and other processes are based on the water system and hence the river basin or catchment is still the preferred boundary when analyzing water resource flows.

\subsection{Water-Energy-Food Nexus}

The question of boundaries in the WEF Nexus is not straightforward. While several authors address the issues of scales, there is no consideration or description of what exactly the water-energy-food system is and by which boundary it is enclosed. The dimensions of the WEF Nexus-even more than in the upper approaches-occur through their interlinkages at various and overlapping scales. It is widely accepted so far that the WEF Nexus must understand and address its dimensions across all scales; what this means and how this is connected to system boundaries remains unclear.

In contrast to other system approaches, the WEF Nexus has to consider and understand three different systems or sectors-agriculture, energy and water-and the interlinkages occurring at different and overlapping levels. Leck et al. [29] describe that interventions through the food, energy or water sectors need to carefully consider the entry point. This makes the consideration of boundaries so central to the Nexus Approach (ibid.). That the WEF Nexus considers the interlinkages of these three critical sectors is indeed a strength of the approach. 
After the WEF Nexus gained popularity in 2011, it seems to be the common understanding that the Nexus Approach must be considered at all scales or across scales respectively [19,29,53,54], or at least at different scales $[20,53,55]$. What is exactly meant with the term "scale" in these cases is ambiguous. Authors refer to scales e.g., in terms of governance and decision making $[19,29,54]$, local, national, global etc. $[19,20,53,54]$ or spatial scale $[19,20,29,53,54]$. The authors do not further describe these terms. When speaking of scales, no boundary considerations are made that explain the extent of the water-energy-food system and clarify how systems analysis can investigate the WEF Nexus.

\section{What Is Different This Time?-The Boundary of the Water-Soil-Waste Nexus System}

The three integrated approaches (INRM, IWRM, ISWM) discussed above have some commonalities regarding the boundaries marking the respective system (see Table 1). They consider the system boundaries of the central compartment marking what system is analyzed, including interlinkages to related compartments or resources. For example, in IWRM the water system is often analyzed within the boundaries of the basin in which its interlinkages with land and other related resources are assessed. The WEF Nexus reveals that the interlinkages of the three sectors are increasingly complex as interlinkages range from a local level (e.g., villagers' deforestation for fuel resulting in decreasing water quality of local water resources through erosion) to a global level (global trade in fossil fuels, bioenergy, food and virtual water). Drawing distinct boundaries to assess those varying levels of interlinkages to assess their trade-offs and synergies basically becomes impossible.

Table 1. Integrated management approaches consider different systems and boundaries for their systems analyses and entail different strengths and weaknesses.

\begin{tabular}{ccccc}
\hline $\begin{array}{c}\text { Considered } \\
\text { system }\end{array}$ & Waste system & INRM & IWRM & WEF Nexus \\
\hline Derived from & Municipal administration & $\begin{array}{c}\text { Ecological and } \\
\text { administrative boundaries }\end{array}$ & Hydrologic cycle & $\begin{array}{c}\text { Water-, Energy-, } \\
\text { Food System }\end{array}$ \\
\hline Boundaries & $\begin{array}{c}\text { Municipality to } \\
\text { intermunicipality }\end{array}$ & Farm to ecoregion & $\begin{array}{c}\text { Catchment (any size) to } \\
\text { river basin }\end{array}$ & $\begin{array}{c}\text { Multiple and } \\
\text { unclearly defined }\end{array}$ \\
\hline Strengths & $\begin{array}{c}\text { Clearly defined by } \\
\text { municipal boundaries }\end{array}$ & Tangible focus on the farm level & Hydrologically useful & $\begin{array}{c}\text { Considers critical and } \\
\text { interlinked sectors }\end{array}$ \\
\hline Weaknesses & $\begin{array}{c}\text { Boundary definition is } \\
\text { ambiguous when exceeding } \\
\text { the municipality }\end{array}$ & $\begin{array}{c}\text { Unclear or unpractical use of } \\
\text { boundary considerations when } \\
\text { exceeding the farm level }\end{array}$ & $\begin{array}{c}\text { Altered hydrological } \\
\text { usefulness through interbasin } \\
\text { transfer (real and virtual water) }\end{array}$ & $\begin{array}{c}\text { Boundaries are not } \\
\text { explained or defined. }\end{array}$ \\
\hline
\end{tabular}

When analyzing the interlinkages of water, soil and waste, how are the boundaries to be drawn? From the analysis above (see Table 1), we discovered that the water system, e.g., within IWRM, is analyzed at the basin or catchment level; the soil system, as per INRM, functions from farm level to ecoregion; and the waste system, as in the ISWM, is analyzed within the boundaries of a municipality or between them. We learned from the analysis of the integrated systems that the boundaries of the systems need to be (a) wide enough (to avoid microanalyses of plot levels as in some cases of INRM), (b) clear (to avoid confusion as in the WEF Nexus), and (c) flexible enough to accommodate varying needs (to avoid geographic constrictions as is the case of the basin discussions in IWRM).

The goal of the WSW Nexus is to increasingly understand the interlinkages between the three resources: water, soil and waste. Analyzing the WSW Nexus within the boundaries of only the watershed, just an ecosystem or exclusively within a municipality, will not necessarily properly consider the WSW Nexus system as a whole and hence not be wide enough. However, to be as clear as possible, the WSW Nexus will have to operate within the smallest common geographic area of the physical interlinkages of the three resources, e.g., at the overlap of the resources systems under investigation. The overlap of the two or more resources systems and thus their interlinkages vary significantly depending on the context they are investigated at thus allowing for the needed flexibility 
of its boundary. We define the boundary of systems analysis under the WSW Nexus as the geographic area where at least two systems overlap and thus form the WSW Nexus system.

Whereas processes within each of the resource's systems, namely the water system, the soil system and the waste system, will have to be analyzed, they are considered to be external to the system of the WSW Nexus and their results will be considered as external inputs (see Figure 1).

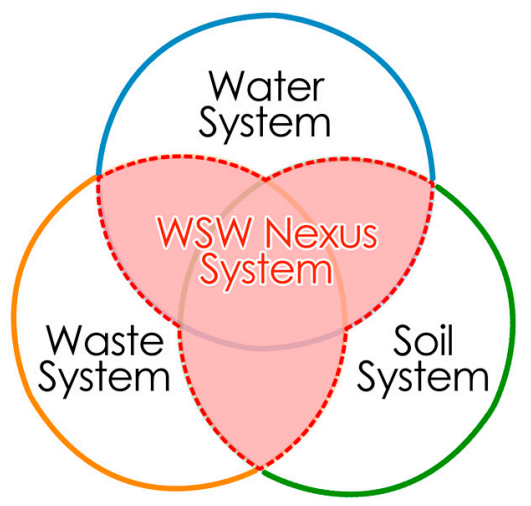

Figure 1. The water-soil-waste (WSW) Nexus system as the area where at least two resources systems overlap.

The results of the processes occurring within each system analyzed within their respective boundaries, i.e., water at the basin level, soil at the farm level, and waste (water) at the municipal level, will serve as input values to the WSW Nexus system. Of particular interest are the points in a resource flow or chain, where the interaction of the two systems is apparent. The WSW Nexus system itself will however not carry out the relevant analyzes of the processes of the underlying individual resource systems (e.g., hydrological modelling of the catchment to assess the changes in flow). The WSW Nexus system will take these external values, from the respective systems specialists, as drivers and inputs to the analysis of the interlinkages of the overlap.

The analysis of physical interlinkages within this system should ultimately aim at revealing benefits through increased resource use efficiency. There are different examples of benefits due to increased resource use efficiency. They can be direct efficiencies such as enhanced crop yields due to application of recycled nutrients or irrigation strategies, increased water productivity through industrial reuse or reduced waste (sludge, wastewater) from wastewater treatment plants through reuse. Resource use efficiency can however also extend towards more indirect, socioeconomic benefits such as food and energy security, increased public health and better risk management.

\section{Illustrating the Boundaries of the WSW Nexus System-Case Studies}

The WSW Nexus has so far not been applied extensively in situ. Below we will consider two cases to showcase the added value of assessing resource flows in an interconnected manner under the WSW Nexus. They illustrate how the boundaries of the WSW Nexus system facilitate assessing the interlinkages of these resources and material fluxes.

The first case study (see Section 5.1) illustrates a problem that is typically assessed in a disconnected manner either at the catchment level, a farm level, or within a municipality. By assessing resource fluxes individually, other resource flows and respective benefits are omitted. We argue that assessing interconnected resource flows opens up avenues for asking different questions and therefore also obtaining new answers, such as safe wastewater reuse in agriculture for enhanced yields, or managed aquifer recharge through interbasin transfer. The view through the lens of the WSW Nexus boundaries helps on the one hand to assess these resource flows in this new context, but restricts this analysis to a clearly defined geographic area on the other hand, thus reducing unnecessary complexity of the problem. By considering the inputs of the respective water, soil and waste systems as external 
factors and drivers into the WSW Nexus system, the issue of the boundaries of those systems is deferred to the respective systems and thus the respective subject matter experts (e.g., hydrologists to determine the size of the catchment to assess the water quantity entering the WSW Nexus system).

The second case study (see Section 5.2) shows the WSW Nexus system on a confined geographic area, that of an industrial park. Again the perspective of the WSW Nexus helps assess resource flows in combination, in this case those of water and waste (water), instead of analyzing each resource system independently. By doing so, clear benefits can be derived. The material flux analysis reveals benefits in the form of freshwater savings and reduced wastewater disposal necessities. The view through the lens of the WSW Nexus system helped disclose these benefits.

\subsection{Mexico City and Mezquital Valley}

\subsubsection{The Benefit of Interlinked Resource Assessment under the WSW Nexus}

With more than 20 million inhabitants, rapidly growing Mexico City is among the world's largest metropolitan areas. This has caused serious human and environmental health concerns going far beyond its administrative municipality's boundary, e.g., [56-58]. As the city has no wastewater treatment system, a $32 \mathrm{~km}$ long tunnel (6 m in diameter) was constructed in 1900 to take rainwater and wastewater from the naturally closed drainage basin of Mexico City to the Mezquital Valley situated $80 \mathrm{~km}$ north of the city.

About $60 \mathrm{~m}^{3} / \mathrm{s}$ is discharged into the Mezquital Valley by the network of channels and tunnels [59]. The Mezquital Valley is the largest agricultural area irrigated with untreated wastewater in the world, with an area of 90,000 ha [60]. The use of wastewater represents a valuable resource in regional agricultural production, due to: (i) the continuous supply of irrigation water; and (ii) the repeated nutrient input to the soil [61]. As a result, wastewater irrigated agriculture provides five times the maize yield (10.0 t/ha) than rainfed maize $(2.0 \mathrm{t} / \mathrm{ha})[62,63]$. Other crops such as lucerne or fodder oats as well as vegetables are also produced. Three agricultural districts (Tula, Alfajayucan and Ajacuba) are directly benefitting from this wastewater irrigation scheme [63]. In terms of water balance, Hernandez-Espriu et al. [59] further pointed out that the transition from unmanaged to managed aquifer recharge is expected to provide multiple benefits to the inhabitants of the valley.

Several scientific studies describe specific impacts of serious health-related and environmental issues [61] and support the recent opinion of Siebe et al. [63], who concluded there is a need to improve the ongoing management of the system.

\subsubsection{The Boundaries of the WSW Nexus}

Assessing the interlinkages of the resources water, soil and waste reveals agricultural benefits within the Mezquital valley. If we limit our toolbox to the known systems analyses (INRM, ISWM, IWRM), defining the optimal boundaries for the analysis of interconnected resource flows becomes difficult.

(1) Water: Basin boundary—not (or partly) applicable (interbasin transfer; anthropogenic wastewater transfer from the endorheic basin of Mexico City to the neighboring basin of the Mezquital Valley).

(2) Soil: Plot level or agroecosystem level—partly applicable (considering wastewater as an input into the system).

(3) Waste: Municipal administrative boundary—not applicable (the wastewater that is produced in one state is transferred to another: Mexico state vs. Hidalgo state).

Therefore, all the existing approaches defined by a resource-specific boundary (INRM, ISWM, IWRM) are failing in the attempt to capture the boundaries for the assessment of resource flows in this case. The WSW Nexus system, being defined as the geographic area where at least two systems overlap, in this case relates to the fields (soil system) that receive the wastewater (waste system) from Mexico City. The WSW Nexus system reveals benefits through increased resource 
use efficiency, which in this case is given by the increased yields in the areas irrigated with wastewater. Figure 2 describes the WSW Nexus system of this case study in a conceptual way.

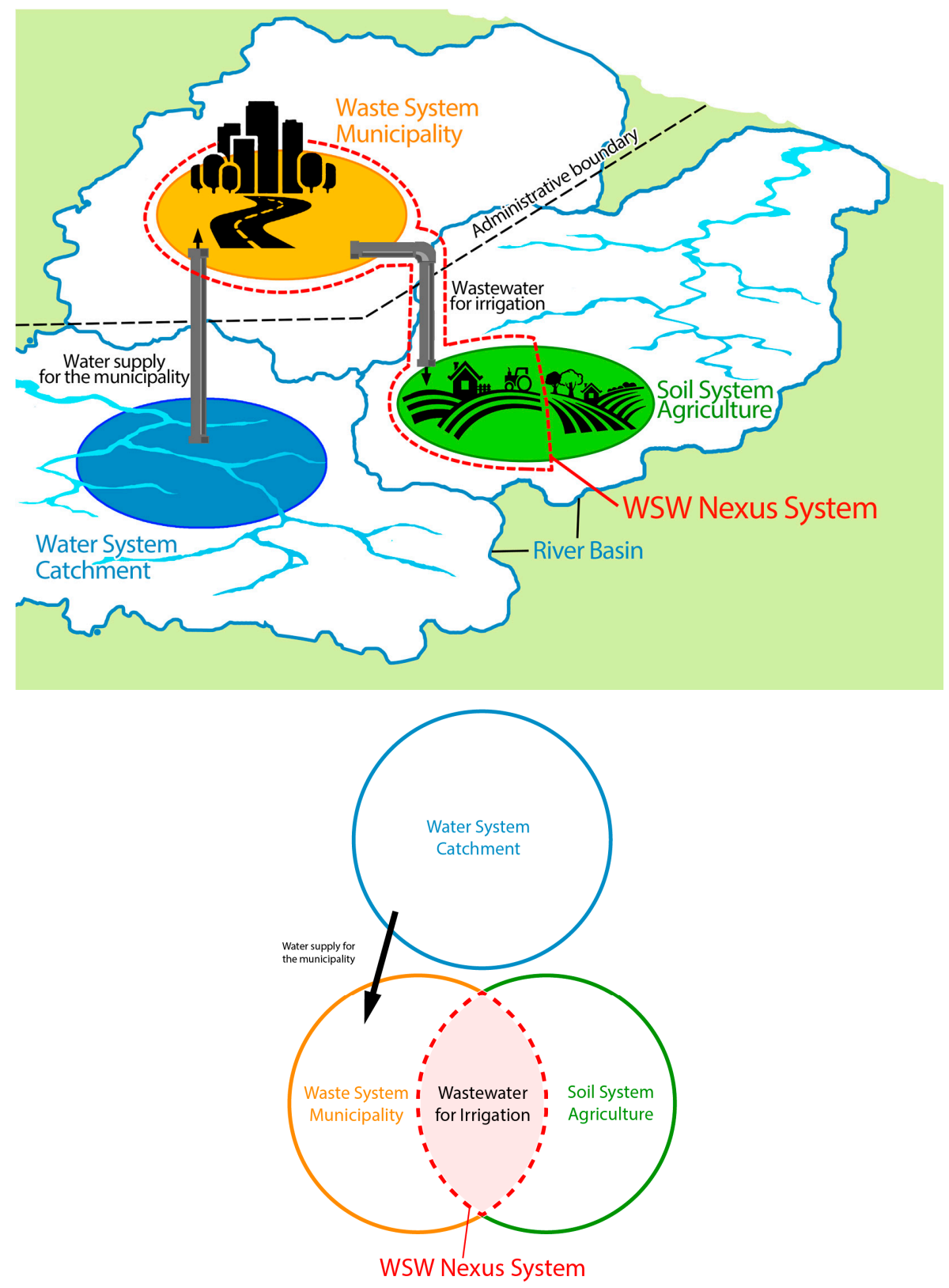

Figure 2. The WSW Nexus system is bound by the overlap of the wastewater system of the municipality and its use for irrigation on the soil system of the agroecosystem. The water system is external to the WSW Nexus system providing the water to the waste system. (The figures show a concept and do not reflect actual geographic information).

In this system, we consider the amount of water entering the overall water-wastewater scheme $\left(81.9 \mathrm{~m}^{3} / \mathrm{s}\right)$ as an external input from the water system to the WSW Nexus system [64]. The same applies to the inherent condition of the soil (e.g., nutrient content, type of soil, etc.) or the quality of the wastewater (e.g., existence of treatment system). This intends to reduce the overall complexity of the analysis to be able to focus exclusively on the interconnections of resources to reveal benefits of combined assessment. The boundaries of the respective water, soil and waste systems are however 
still defined by their respective scholars (e.g., the plot level for assessing soil fertility changes by soil scientists).

\subsection{Mourcheh Khort Industrial Park}

\subsubsection{The Benefit of Interlinked Resource Assessment under the WSW Nexus}

The model settlement Mourcheh Khort is an existing industrial park in the Isfahan province in central Iran, which is used to develop an eco-industrial park (EIP) concept through industrial symbiosis as part of a German-Iranian IWRM research project [65]. Mourcheh Khort is located about $50 \mathrm{~km}$ north of the city of Isfahan in the catchment area of the Zayandeh Rud. Approximately 500 small and medium sized industrial units with in total 17,000 employees from the food, metal, mineral, textile, plastics, paper and chemical industries are located on 582 hectares.

Process water in the model settlement originates partly from a central supply network fed by a large deep well but mainly from private wells at each factory. Groundwater from these wells is often pretreated by reverse osmosis on-site to reduce salinity and hardness. According to interviews with industry managers, water tables of private wells have been dropping severely due to overuse and drought in the past years (pers. comm. W. Raber with industries in Mourcheh Khort, 2016).

Wastewater from industries is mainly disposed to the sewage system connected to a central treatment plant constructed in 2011 [66]. However, particularly industries with small wastewater production dispose their water often by tankers outside of the industrial park, in order to save costs for connection to the sewage system (pers. commun. W. Raber with Park Management Mourcheh Khort, 2016).

The anthropogenic cycles of the industrial ecology follow three principles of interrelating mechanisms: (a) the bilateral principle (simple connection between two industries), (b) the nucleus principle (connection from one to several other industries), or (c) the cascade principle (a comparatively complex series of bilateral links) [67]. A material flow analysis (MFA) was applied to quantify the industrial water use applying STAN (subSTance flow Analysis, [68]).

The results of the case study (see Table 2) show that depending on the interlinking principle, a different stage of water-saving efficiency can be achieved. The focus of industrial symbiosis is on beneficial interfaces between companies through their material fluxes with the overall scope of a circular economy for water, waste, energy, and information. In this way, industrial symbiosis can be considered per se as a Nexus based concept. A view on industrial symbiosis under a Nexus Approach leads to a changed perspective on substances and energy cycles, from the life cycle of a product or service to the life cycle of a resource as compartment of the natural capital [69]. From our point of view, the discussed bilateral, nucleus and cascade principle can be used to assess different types of resource flows within the WSW Nexus.

Table 2. Potential reductions and savings in water consumption and wastewater production relative to the different interrelating mechanisms of the eco-industrial park (EIP).

\begin{tabular}{cll}
\hline \multicolumn{1}{c}{ Principle } & \multicolumn{1}{c}{ Industries Connected } & \multicolumn{1}{c}{ Reductions and Savings } \\
\hline Bilateral principle & $\begin{array}{l}\text { Polyamide fiber production } \rightarrow \\
\text { dyeing factory }\end{array}$ & $\begin{array}{l}\text { Fresh water consumption can be } \\
\text { reduced by 33\% of the total water } \\
\text { demand of the two industries }\end{array}$ \\
\hline Nucleus principle & $\begin{array}{l}\text { Milk powder production (nucleus) } \rightarrow \\
\text { multiple connected industries (consumers) }\end{array}$ & $\begin{array}{l}\text { Fresh water savings potentials of } \\
92 \% \text { and sewage savings of } 67 \%\end{array}$ \\
\hline \multirow{2}{*}{ Cascade principle } & $\begin{array}{l}\text { Polyamide fiber production } \rightarrow \text { poly-tube } \\
\text { production } \rightarrow \text { two different metal } \\
\text { processing plants }\end{array}$ & $\begin{array}{l}\text { Total savings of approx. 56\% of } \\
\text { the fresh water demand and } \\
\text { approx. 83\% of the wastewater }\end{array}$ \\
\hline
\end{tabular}




\subsubsection{The Boundaries of the WSW Nexus}

The scope of the case study was to assess the benefits from assessing the resources water and waste in an interlinked manner in order to close the wastewater cycles between the companies. Different EIP design scenarios considered varying levels of interindustrial water reuse without additional water supply for the connected water fluxes.

This case study shows the benefit-scale at the sublocal level in an industrial park. The two systems of water and waste overlap with the boundary of the industrial park itself. Figure 3 describes the WSW Nexus system of this case study in a conceptual way. It shows an example of one modeled scenario in the industrial park, where wastewater from one industry can be used as process water in several other industries.

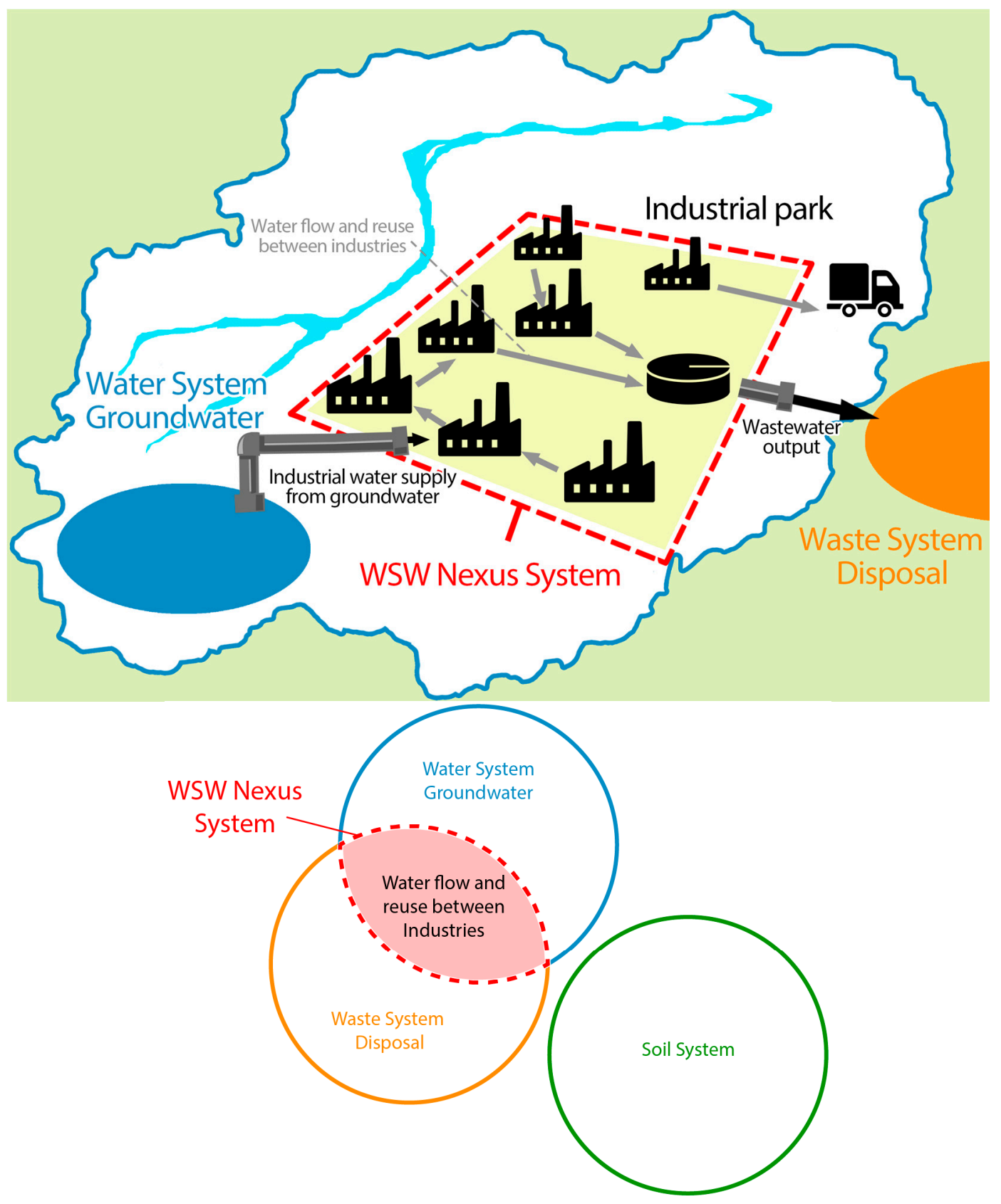

Figure 3. The WSW Nexus system is bound by the overlap of the water and the waste system where wastewater can be reused by other industries as intake. The soil system is external to the WSW Nexus system. (The figures show a concept and do not reflect actual geographic information). 


\section{Conclusions}

In this study we examined the boundaries of systems analysis in ISWM, INRM, IWRM and the WEF Nexus. We derived three criteria for defining systems boundaries for integrated management, namely: wide, clear and flexible. The WSW Nexus system is designed to fit those criteria. It reduces the overall level of complexity of the nexus problem without ignoring that the complexity is inherent to each of the three underlying systems.

This deliberately stands in contrast to prominent thoughts in the WEF Nexus community (e.g., $[19,21,53,54])$. The unmanageable complexity of the WEF Nexus has been criticized (see e.g., [1,29]). The WSW Nexus system as described here intends to provide a clear definition. We are conscious of the fact that the analysis of (bio-)physical interlinkages alone is not sufficient to achieve sustainable management. Socioeconomic, political, and institutional aspects need to be taken into account as well. Nonetheless, we consider (bio-)physical interlinkages to be the basis for any further analysis. Going forward, the concept of the WSW Nexus system can be elaborated on by moving from the biophysical interlinkages towards their implications of socioeconomic and political issues, thus creating a "benefit-shed". It remains to be assessed if the boundaries of the WSW Nexus system are as useful to these further dimensions as they are to the assessment of interlinked resources.

Acknowledgments: The authors would like to thank the comments of the two anonymous reviewers. These helped shape the article in its current form. Tamara Avellán thanks the German Federal Ministry of Education and Research (BMBF) and the Saxon State Ministry for Science and the Arts (SMWK) for providing research funding for UNU-FLORES. Mario Roidt coauthored this article as part of the Master's Program "Hydro Science and Engineering" at Technische Universität Dresden. He is a scholar of the German Academic Scholarship Foundation and expresses his gratitude for the financial support that made his research at UNU-FLORES possible. The research of Adam Emmer at UNU-FLORES was supported by the Czech Ministry of Education, Youth and Sports within the National Sustainability Program I (NPU I), grant number LO1415. For supporting the Mexico Valley case study we want to express our gratitude to Christina D. Siebe Grabach. For funding and facilitating the work in Mourcheh Khort, Iran we acknowledge the BMBF, the Iranian Ministry of Energy and the Esfahan Regional Water Company. The funding for the publishing of the article was provided through the Chair for International Water Management at the University of Applied Sciences Magdeburg-Stendal, Petra Schneider. A big thank you goes to Sungbong Lee, intern at UNU-FLORES (February-July 2017), for designing the figures in this article. His internship was funded by the Government of Korea.

Author Contributions: The concept of the article and the WSW Nexus System was developed at UNU-FLORES by T. Avellán and M. Roidt in close collaboration with A. Emmer and the other coauthors. The introduction was written by T. Avellán, M. Roidt and P. Schneider. Sections 2 and 3 where written by M. Roidt with the exception of Section 2.5 which was provided by T. Avellán. Section 4 was written by T. Avellán and M. Roidt. A. Emmer contributed the case study in Section 5.1. J. von Koerber, P. Schneider and W. Raber provided the case study in Section 5.2. Section 6 was written by T. Avellán and M. Roidt. All sections have been commented by the coauthors and include their views.

Conflicts of Interest: The authors state no conflicts of interest.

\section{References}

1. Wichelns, D. The water-energy-food nexus: Is the increasing attention warranted, from either a research or policy perspective? Environ. Sci. Policy 2017, 69, 113-123. [CrossRef]

2. Biswas, A.K. Integrated water resources management: A reassessment: A water forum contribution. Water Int. 2004, 29, 248-256. [CrossRef]

3. White, G.F. Reflections on the 50-year international search for integrated water management. Water Policy 1998, 1, 21-27. [CrossRef]

4. Mukhtarov, F.G. Intellectual History and Current Status of Integrated Water Resources Management: A Global Perspective; Springer: Berlin, Germany, 2008.

5. Jeffrey, P.; Gearey, M. Integrated water resources management: Lost on the road from ambition to realisation? Water Sci. Technol. 2006, 53, 1-8. [CrossRef] [PubMed]

6. Biswas, A.K. Integrated Water Resources Management: Is It Working? Int. J. Water Resour. Dev. 2008, 24, 5-22. [CrossRef] 
7. CGIAR Task Force on Natural Resource Management. Integrated Natural Resource Management Research in the CGIAR: A Brief Report on the INRM Workshop Held in Penang, Malaysia, 21-25 August 2000; CGIAR: Washington, DC, USA, 2000.

8. Campbell, B.; Sayer, J. (Eds.) Integrated Natural Resource Management: Linking Productivity, the Environment, and Development; CABI Pub. in Association with the Center for International Forestry Research (CIFOR): Oxon, UK; Cambridge, MA, USA, 2003.

9. McDougall, F.R.; White, P.; Franke, M.; Hindle, P. (Eds.) Integrated Solid Waste Management: A Life Cycle Inventory, 2nd ed.; Blackwell Science: Oxford, UK; Malden, MA, USA, 2001.

10. Marshall, R.E.; Farahbakhsh, K. Systems approaches to integrated solid waste management in developing countries. Waste Manag. 2013, 33, 988-1003. [CrossRef] [PubMed]

11. Hagmann, J.; Chuma, E.; Murwira, K.; Connolly, M.; Ficarelli, P.P. Success Factors in Integrated Natural Resource Management R\&D: Lessons from Practice. In Integrated Natural Resource Management: Linking Productivity, the Environment, and Development; Campbell, B., Sayer, J., Eds.; CABI Pub. in Association with the Center for International Forestry Research (CIFOR): Oxon, UK; Cambridge, MA, USA, 2003; Chapter 1; pp. 37-64.

12. Savenije, H.H.G.; van der Zaag, P. Integrated water resources management: Concepts and issues. Phys. Chem. Earth 2008, 33, 290-297. [CrossRef]

13. Smithson, P.; Addison, K.; Atkinson, K. Fundamentals of the Physical Environment, 4th ed.; Routledge: London, UK; New York, NY, USA, 2008.

14. Bennett, R.J.; Chorley, R.J. Environmental Systems: Philosophy, Analysis and Control; Princeton University Press: Princeton, NJ, USA, 1978.

15. Park, C. The Environment Principles and Applications, 2nd ed.; Routledge: London, UK; New York, NY, USA, 2001.

16. Meadows, D.H.; Wright, D. Thinking in Systems: A Primer; Earthscan: London, UK, 2009.

17. Mandelbrot, B.B. Scalebound or Scaling Shapes: A Useful Distinction in the Visual Arts and in the Natural Sciences. Leonardo 1981, 14, 45-47. [CrossRef]

18. GWP. Integrated Water Resources Management; Global Water Partnership: Stockholm, Sweden, 2000.

19. Hoff, H. Understanding the Nexus. Background Paper for the Bonn 2011 Conference: The Water, Energy and Food Security Nexus; Stockholm Environment Institute (SEI): Stockholm, Sweden, 2011.

20. Endo, A.; Burnett, K.; Orencio, P.M.; Kumazawa, T.; Wada, C.A.; Ishii, A.; Tsurita, I.; Taniguchi, M. Methods of the Water-Energy-Food Nexus. Water 2015, 7, 5806-5830. [CrossRef]

21. Al-Saidi, M.; Elagib, N.A. Towards understanding the integrative approach of the water, energy and food nexus. Sci. Total Environ. 2017, 574, 1131-1139. [CrossRef] [PubMed]

22. Cairns, R.; Krzywoszynska, A. Anatomy of a buzzword: The emergence of 'the water-energy-food nexus' in UK natural resource debates. Environ. Sci. Policy 2016, 64, 164-170. [CrossRef]

23. Schwärzel, K.; Huelsmann, S.; Ardakanian, R. UNU-FLORES: Advancing a Nexus Approach to the Sustainable Management of Water, Soil and Waste. In White Book on Advancing a Nexus Approach to the Sustainable Management of Water, Soil and Waste; Huelsmann, S., Ardakanian, R., Eds.; UNU-FLORES: Dresden, Germany, 2014; pp. 3-7.

24. Abounajm, M.; Elfadel, M. Computer-based interface for an integrated solid waste management optimization model. Environ. Model. Softw. 2004, 19, 1151-1164. [CrossRef]

25. Schneider, P.; Anh, L.; Wagner, J.; Reichenbach, J.; Hebner, A. Solid Waste Management in Ho Chi Minh City, Vietnam: Moving towards a Circular Economy? Sustainability 2017, 9, 286. [CrossRef]

26. Allouche, J. The birth and spread of IWRM-A case study of global policy diffusion and translation. Water Altern. 2016, 9, 412-433.

27. United Nations. Transforming Our World: The 2030 Agenda for Sustainable Development; United Nations: New York, NY, USA, 2015.

28. Beddington, J. FOOD, ENERGY, WATER AND THE CLIMATE: A PERFECT STORM OF GLOBAL EVENTS? Available online: http:/ / webarchive.nationalarchives.gov.uk/20121206120858/http:/ /www.bis.gov.uk/ assets / goscience/docs/p/perfect-storm-paper.pdf (accessed on 16 October 2017).

29. Leck, H.; Conway, D.; Bradshaw, M.; Rees, J. Tracing the Water-Energy-Food Nexus: Description, Theory and Practice: Tracing the Water-Energy-Food Nexus. Geogr. Compass 2015, 9, 445-460. [CrossRef]

30. UNU-FLORES. The Nexus Approach to Environmental Resources' Management. 2015. Available online: https:/ / flores.unu.edu/en/research/nexus (accessed on 11 May 2017). 
31. Hülsmann, S.; Ardakanian, R. (Eds.) White Book on Advancing a Nexus Approach to the Sustainable Management of Water, Soil and Waste; UNU-FLORES: Dresden, Germany, 2014.

32. Kurian, M.; Ardakanian, R. (Eds.) Governing the Nexus; Springer International Publishing: Cham, Switzerland, 2015.

33. Memon, M.A. Integrated solid waste management based on the 3R approach. J. Mater. Cycles Waste Manag. 2010, 12, 30-40. [CrossRef]

34. Kollikkathara, N.; Feng, H.; Stern, E. A purview of waste management evolution: Special emphasis on USA. Waste Manag. 2009, 29, 974-985. [CrossRef] [PubMed]

35. Koroneos, C.J.; Nanaki, E.A. Integrated solid waste management and energy production-A life cycle assessment approach: The case study of the city of Thessaloniki. J. Clean. Prod. 2012, 27, 141-150. [CrossRef]

36. Othman, S.N.; Noor, Z.Z.; Abba, A.H.; Yusuf, R.O.; Hassan, M.A.A. Review on life cycle assessment of integrated solid waste management in some Asian countries. J. Clean. Prod. 2013, 41, 251-262. [CrossRef]

37. Geng, Y.; Zhu, Q.; Haight, M. Planning for integrated solid waste management at the industrial Park level: A case of Tianjin, China. Waste Manag. 2007, 27, 141-150. [CrossRef] [PubMed]

38. Menikpura, N.; Sang-Arun, J.; Bengtsson, M. Integrated Solid Waste Management: An approach for enhancing climate co-benefits through resource recovery. J. Clean. Prod. 2013, 58, 34-42. [CrossRef]

39. Brunner, P.H.; Rechberger, H. Practical Handbook of Material Flow Analysis; CRC Press: Boca Raton, MA, USA, 2005.

40. Douthwaite, B.; Ekboir, J.M.; Twomlow, S.; Keatinge, D. The concept of integrated natural resource management (INRM) and its implications for developing evaluation methods. In Natural Resource Management in Agriculture: Methods for Assessing Economic and Environmental Impacts; Shiferaw, B., Freeman, H.A., Swinton, S.M., Eds.; CABI Publishing: Oxfordshire, UK, 2004; pp. 321-340.

41. Twomlow, S.; Love, D.; Walker, S. The nexus between integrated natural resources management and integrated water resources management in southern Africa. Phys. Chem. Earth 2008, 33, 889-898. [CrossRef]

42. Harwood, R.R.; Place, F.; Kassam, A.H.; Gregersen, H.M. International Public Goods through Integrated Natural Resources Management Research in CGIAR Partnerships. Exp. Agric. 2006, 42, 375-397. [CrossRef]

43. Sayer, J.; Campbell, B.M. Research to integrate productivity enhancement, environmental protection, and human development. In Integrated Natural Resource Management: Linking Productivity, the Environment, and Development; Campbell, B.M., Sayer, J., Eds.; CABI Pub. in Association with the Center for International Forestry Research (CIFOR): Oxon, UK; Cambridge, MA, USA, 2003; Chapter 1; pp. 1-14.

44. Graefe, O. River basins as new environmental regions? The depolitization of water management. Procedia Soc. Behav. Sci. 2011, 14, 24-27. [CrossRef]

45. Houdret, A.; Dombrowsky, I.; Horlemann, L. The institutionalization of River Basin Management as politics of scale-Insights from Mongolia. J. Hydrol. 2014, 519, 2392-2404. [CrossRef]

46. Rahaman, M.M.; Varis, O. Integrated water resources management: Evolution, prospects and future challenges. Sustain. Sci. Pract. Policy 2005, 1, 15-21.

47. Jønch-Clausen, T.; Fugl, J. Firming up the Conceptual Basis of Integrated Water Resources Management. Int. J. Water Resour. Dev. 2001, 17, 501-510. [CrossRef]

48. UNESCO. Facing the Challenges; UNESCO: Paris, France, 2012.

49. Petit, O. Paradise lost? The difficulties in defining and monitoring Integrated Water Resources Management indicators. Curr. Opin. Environ. Sustain. 2016, 21, 58-64. [CrossRef]

50. Santos, P.M.; Aldaya, M.; Llamas, M.R. Integrated Water Resources Management: State of the art and the way forward. In Integrated Water Resources Management in the 21st Century: Revisiting the Paradigm; Santos, P.M., Aldaya, M., Llamas, M.R., Eds.; CRC Press, Taylor \& Francis Group: Boca Raton, MA, USA, 2014; pp. 17-36.

51. Gupta, J.; van der Zaag, P. Interbasin water transfers and integrated water resources management: Where engineering, science and politics interlock. Phys. Chem. Earth Parts ABC 2008, 33, 28-40. [CrossRef]

52. Giordano, M.; Shah, T. Non-Integrated Water Resources Management. In Integrated Water Resources Management in the 21st Century: Revisiting the Paradigm; Santos, P.M., Aldaya, M., Llamas, M.R., Eds.; CRC Press, Taylor \& Francis Group: Boca Raton, MA, USA, 2014; pp. 37-46.

53. Lawford, R.; Bogardi, J.; Marx, S.; Jain, S.; Wostl, C.P.; Knüppe, K.; Ringler, C.; Lansigan, F.; Meza, F. Basin perspectives on the Water-Energy-Food Security Nexus. Curr. Opin. Environ. Sustain. 2013, 5, 607-616. [CrossRef]

54. Yillia, P.T. Water-Energy-Food nexus: Framing the opportunities, challenges and synergies for implementing the SDGs. Oesterreichische Wasser- und Abfallwirtschaft 2016, 68, 86-98. [CrossRef] 
55. Ringler, C.; Bhaduri, A.; Lawford, R. The nexus across water, energy, land and food (WELF): Potential for improved resource use efficiency? Curr. Opin. Environ. Sustain. 2013, 5, 617-624. [CrossRef]

56. Connolly, P. Mexico City: Our common future? Environ. Urban. 1999, 11, 53-78. [CrossRef]

57. Raga, G.B.; Baumgardner, D.; Castro, T.; Martinez-Arroyo, A.; Navarro-Gonzalez, R. Mexico City air quality: A qualitative review of gas and aerosol measurements (1960-2000). Atmos. Environ. 2001, 35, 4041-4058. [CrossRef]

58. Aguilar, A.G. Peri-urbanization, illegal settlements and environmental impact in Mexico City. Cities 2008, 25, 133-145. [CrossRef]

59. Hernandez-Espriu, A.; Arango-Galván, C.; Reyes-Pimentel, A.; Breña-Naranjo, J.A. Water Supply Source Evaluation in Unmanaged Aquifer Recharge Zones: The Mezquital Valley (Mexico) Case Study. Water 2017, 9, 4. [CrossRef]

60. Bouchez, C.A.P. Council for certification of irrigation with treated water in Mexico (Mexico). In Safe Use of Wastewater in Agriculture: Good Practice Examples; UNU-FLORES: Dresden, Germany, 2016; pp. 121-138.

61. Siebe, C.; Cifuentes, E. Environmental impact of wastewater irrigation in central Mexico: An overview. Int. J. Environ. Health Res. 1995, 5, 161-173. [CrossRef]

62. Conagua-Comisión Nacional del Agua. Estadísticas Agrícolas de los Distritos de Riego. Año 2007-2008; Secretariat of Environment and Natural Resoureces: Mexico City, Mexico, 2010.

63. Siebe, C.; Chapela-Lara, M.; Cayetano-Salazar, M.; Prado, B.; Siemens, J. Effects of more than 100 years of irrigation with Mexico Coty's wastewater in the Mezquital Valley (Mexico). In Safe Use of Wastewater in Agriculture: Good Practice Examples; UNU-FLORES: Dresden, Germany, 2016; pp. 279-299.

64. THE INNOVATIVE METROPOLIS: FOSTERING ECONOMIC COMPETITIVENESS THROUGH SUSTAINABLE URBAN DESIGN. Washington University in St. Louis. 2013. Available online: https: / /www.brookings.edu/wp-content/uploads/2013/02/Mexico_City.pdf (accessed on 17 October 2017).

65. Raber, W.; Mohajeri, S. Current and Future Industrial Water Use in the Zayandeh Rud Catchment. In Reviving the Dying Giant-Integrated Water Resource Management in the Zayandeh Rud Catchment, Iran; Mohajeri, S., Horlemann, L., Eds.; Springer International Publishing: Cham, Switzerland, 2017; pp. 95-115.

66. Piadeh, F.; Moghaddam, M.R.A.; Mardan, S. Present situation of wastewater treatment in the Iranian industrial estates: Recycle and reuse as a solution for achieving goals of eco-industrial parks. Resour. Conserv. Recycl. 2014, 92, 172-178. [CrossRef]

67. Von Koerber, J. Concept for the Resource-Efficient Use of Water Using the Example of the Development of Eco Industrial Parks in Iran. Master's Thesis, University of Applied Sciences Magdeburg-Stendal, Magdeburg, Germany, 2016.

68. Cenic, O.; Rechenberger, H. Material Flow Analysis with Software STAN. J. Environ. Eng. Manag. 2008, 18, 440-447.

69. Schneider, P.; Lüderitz, V. Integration of Ecosystem Services as Part of the Nexus Approach into the Applied Teaching of Ecological Engineering. In Handbook of Sustainability Science and Research; Leal, W., Ed.; Springer: Berlin, Germany, unpublished.

(C) 2017 by the authors. Licensee MDPI, Basel, Switzerland. This article is an open access article distributed under the terms and conditions of the Creative Commons Attribution (CC BY) license (http://creativecommons.org/licenses/by/4.0/). 